\title{
Play on words and their functions in Javanese cartoons
}

\author{
I Dewa Putu Wijana \\ Faculty of Cultural Sciences, Universitas Gadjah Mada, Yogyakarta, Indonesia \\ e-mail: idp_wijana@yahoo.com
}

\begin{abstract}
This article is intended to describe linguistic aspects played by the cartoonist in creating jocular discourse and to view how those discourses are also exploited to deliver social criticisms against various social phenomena happens in the Javanese community. All data presented are collected from Djoko Lodang, one of about three Javanese magazines that is nowadays still published in Java. After having carefully analyzed the data collection, it is found that there are many kinds of linguistic aspects which are very common to be used for creating humorous texts. Those are sound change, polysemy, idiom, homonymy, antonymy, hyponymy, and pragmatic usage. Even though most of the discourses are created to carry out their primary function for expressing jokes, many of them are also made for delivering social criticisms, such as criticism against social poverty, injustice, betrayal and dishonesty, impoliteness, crimes, violence, environmental destruction, etc. These findings indicate that study on cartoon discourse from various perspectives, particularly from the linguistic viewpoint, plays a very central role, in order to understand and to solve social problems occur in the society.
\end{abstract}

\section{Keywords}

cartoon, discourse, humor, joke, textkey

\section{Introduction}

Javanese is one of the most prominent languages spoken in Indonesia. It is the native tongue of about 75 million people, or $40 \%$ of the Indonesian total population (Moeliono, 2011, p. 130). Nevertheless, Javanese is not the national or official language in this linguistic diverse country. The Indonesian youths through their pledge which is famously known as "Soempah Pemoeda" in 1928 had declared Malay which is only used by no more than $30 \%$ to be their national language (Anwar, $1980,1)$, and through one of the state constitution article, this language gets its additional status as the official language. This decision is mainly based on the long-time use of Malay as a lingua franca over Indonesian archipelago, and the complexity of the Javanese speech levels that is considered unsuitable to represent solidarity in struggling against colonialism to reach independence (Holmes, 1992, p. 112). This political decision brings a big impact toward the Javanese fate. Because of the higher status of Malay which is later called Bahasa Indonesia, after independence, all Javanese speakers belonging to the younger generation, are more interested to master Bahasa Indonesia and slowly 
becoming less sufficient in their mother tongue. Bahasa Indonesia is the medium of instruction. All subjects are taught in Bahasa Indonesia. Javanese, like other Indonesian local languages, is only used from the first year to the third year in rural elementary schools. After the students get used to Bahasa Indonesia, the instruction completely transfers into Bahasa Indonesia. This phenomenon is commonly called subtractive bilingualism (Romaine, 1989, pp. 107-108; Wijana, 2003, p. 249) which may bring bad effects because the learner will gradually lose their first language. Even, in Javanese urban areas, the instruction using Bahasa Indonesia starts earlier. Nowadays, Javanese is merely a regional language that is used by its speakers as a means of communication limited in an informal situation in East and Middle Java.

Even still far from the status though of an endangered language, it seems quite reasonable for the Javanese leaders to worry about the existence and the sustainability of their ancestor's language in competing with other bigger and more prestigious languages in the global era. The condition use of Javanese, from time to time is getting more and more apprehensive. The existence of its competent speakers is decreasing year by year. A lot of Javanese use domains are already replaced using Bahasa Indonesia, and many more will be so in not very far future because the younger Javanese generation is more fluent in speaking Bahasa Indonesia compared to their own native language. To avoid the extinction of Javanese, the Indonesian government has made the following language policy in explaining the government attitude concerning the status of all local languages used in Indonesia (Halim, 1981, p. 21):

"Local languages that are still used as means of communication by their community speakers are respected and preserved because they are a part of Indonesian alive culture."

However, the more prospective national and foreign languages, such as English, French, Germany, and several influential Asian languages (Japan, Korean, Mandarin, etc.) directly cause the decline use of Javanese and other local languages, especially among their younger generation. For the younger generations, improving Javanese and other local languages mastery, will not assure them to promote their future carrier prospect because of the very limited occupation or job opportunity might these languages offer compared to the national and foreign language mastery. As result, in diglossic situation, the use of Javanese is rarely found in a formal situation, except in very specific traditional ceremonies, such as a wedding, funeral, etc.

No matter how apprehensive the condition use of the Javanese is, the central government through its language body (Badan Bahasa) commits to preserve or protect it, along with other local languages from the extinction. Several local governments issuing Javanese speaking day in every week for all staffs of the offices which are under their coordination. Javanese is also taught as a local content subject in elementary, junior and senior high school. Again, because of the great pressures of the national and the big influential foreign languages, the government efforts to maintain the existence of Javanese and improve the quality of its usage especially among the younger speakers are hard to realize. Nevertheless, the relatively stable diglossic situation, between the use of Indonesian as the High variety and the Javanese as the Low one, makes the local languages are still well kept serving the less prestigious communicative activities in informal situations, such as for bargaining in traditional markets, chatting with close friends or relatives, uttering jokes, riddling, etc. Meanwhile, the more formal activities, such as writing an official letter, giving a speech, teaching and lecturing, etc. are conducted in Indonesian.

This paper will try to investigate the use of Javanese for joking activities, one of the informal activities that have not so far been studied seriously by the linguists. This study expectedly will complete the previous studies which have been carried out by Maryaeni (2001) concerning Javanese Ludruk, Pradopo et al (1985) about Humor in Javanese literary works, and Jatmiko (2009) dealing with miscellaneous humorous folklore texts. The joking activities, in a line with informal use of Javanese by which the joke most appropriately to express (Apte, 1985, pp. 190-191; Wijana, 1995, p. 140) are certainly still preserved in the Javanese community because humor in its variety of genres plays an important role in any community because its existence is required to liberate people from any kind of tensions they always faced in carrying out their daily activities (Grotjahn, 1957, pp. 8-9; Raskin, 1984, p. 9). Due to various kinds of humor genre, I will focus my discussion on a genre of Javanese humor texts, i.e. Javanese cartoons which still maintain their existence although written materials in Javanese are recently getting more and more difficult to find. These materials surely give me a lot of eases in that I do not have to conduct complicated recording and transcribing activities before I can analyze them and presenting my findings. 


\section{Theoretical Framework}

In every normal process of communication, it is conventionally assumed that all participants engaged within are tightly governed by pragmatic presumption in which they oblige to behave rationally in delivering their utterances and in comprehending ones of their interlocutors. In this process, the speakers naturally want to inform the hearers and expect them to understand the messages of the utterances the speakers intend to deliver (Allan, 1986, p. 10). Accordingly, any speakers should pack their massage as informative as possible, and the massage must be true or based on adequate evident, relevant to the context and straight forward, not wordy, not ambiguous, and must be expressed in natural way or reasonable manners. According to Grice's (1975, pp. 41-58) conversational theory, all parties must obey cooperative principles. There are 4 maxims that should not be violated by the speaker and the hearer. Those are maxim of quantity which obliges the participants to be brief and as informative as required in every stage of communication process; maxim of quality that urges the participants to be true; maxim of relevance that requires the participant's contribution should always be relevant to the context of the utterances; and maxim of manner which forces the participants to express their utterances in proper manners. All of these rules well operate in normal speech conditions. However, a lot of verbal discourses are created to achieve certain communicative goals. For doing so, the rules which are tightly obeyed in normal conversations are often intentionally flouted (Parker, 1986, pp. 22-23). For example, to gain consumers attention and persuading them to purchase the products being offered, copy writers often violates the quality maxim by constructing or creating utterances which lack of reliable evidences. Likewise, a poet or literary writers also creates hyperbolic utterances for achieving aesthetic effects in their literary works. All of these matters indicate that advertisements and literary works do not constitute conventional discourse which obliges the speakers or the creators to follow conversational maxim rules outlined in Grice's conversation theory.

Conventional discourses, in Raskin (1984, p. 103) theoretical frame work are resulted in bona fide process of communication in which no other communicative goals want to be achieved, except the speakers' intention for the messages they want to deliver to be understood properly by the interlocutors. Like advertisements and literary works, cartoons belong to nonconventional discourse resulted from nonbona fide process of communication in which conversational maxims of cooperative principles are deliberately violated to gain certain communicative effects. In advertorial discourse the copy writer intends to gain persuasive effects. In literary works, the writers want to achieve aesthetic effects, while the cartoonists want to get comic effects from the readers. If the natural situation requires all participants following conversational maxims that oblige them to speak briefly, to be true, to be relevant, and speak straight forward and not ambiguous, in creating jocular discourses they ought to speak in totally different way. Otherwise, the comic effects is difficult to achieve. Therefore, the four Grice's conversational maxims, in term of Raskin's humor theory (1984, p. 103) should be modified as the following formulas:

1. Maxim quantity: Give exactly as much information as is necessary for the joke, instead of giving exactly as much as required.

2. Maxim of quality: Say only what is compatible with the world of joke, instead of saying what you believe to be true.

3. Maxim of relation: say only what is relevant to the joke, instead of being relevant.

4. Maxim of manner: Tell the joke efficiently, instead of being succinct or saying something clearly.

From this modifying conceptual framework, it can be hypothesized that for the sake of effective humor deliverance, humorous discourses, included Javanese cartoons will extensively exploit various kinds of play on words of various linguistic levels which have never been so far seriously studied by the linguists who pay attention on Javanese jocular discourses. Like other genres of discourse, Javanese cartoons are also created to bear several communicative functions in spite of its main function to deliver jokes. This brief paper will explore various types of play on words and their communicative functions to express social criticisms found in Javanese cartoons.

\section{Methods}

All cartoon discourses presented in this paper are taken from Djaka Lodang weekly magazine, one among no more than 3 Javanese magazines of this kind which are nowadays still published in Java. This printing media is published in Yogyakarta which is situated in Yogyakarta Specific Region, one of Javanese used centers beside Surakarta in Middle Java Province. More importantly, this magazine is easy to get and 
subscribe because its adjacent location from my domicile. First of all, Javanese cartoons that show the exploitation of play on words are hierarchically classified on the basis of linguistic aspects played as the source of humor. In spite of its main function to tell a joke, cartoons are also created to bear various social critics. Accordingly, the analysis is also carried out to view various social disapprovals expressed by cartoonist exist in the data collection.

\section{Various Linguistic Aspects Exploited in Javanese Cartoons}

Before arriving at further discussions, it seems important to note that not all jokes found in cartoon discourses are created on the basis of play on words. Some of them are done on the basis of ideas. Such as in discourse (1), the joke is relied on the miss perception of the old person in seeing fruit place like an aquarium. Meanwhile, in (2), the jokes are created on the basis of wrong presupposition of the old person to think that the box is full of food of meat as what usually people gets after attending a ritual feast. The old person has never realized that the box is filled with body organs of a mutilation victim, the shaking event happens in the cartoon creation time.

(1) A: Ngersakake ngrujak seger kwarasa mbahe?

'Do you want to have fresh fruit salad for your health, Grandpa?'

B: Lho: Akuarium kok malah kok isi buah.

'Oh, why do you fill an aquarium with fruits?'

A: Sing suwak iku apa mbahe?

'Who is really mad, I or he?'

(Djaka Lodang, No. 12, 20/8/2016, p. 50)

(2) A: Mentas kendhuri, oleh nuk?

'After attending a ritual feast, did you get meal, Son?'

B: Ampun salah tampa. Kardus niki sanes isi sega lawuh. Nanging barang bukti korban mutilasi bocah.

'Please don't misunderstand, this box does not contain rice and side dishes. But evident of child mutilation.'

(Djaka Lodang, No. 20/17/10/2015, p. 19)

After having observed and analyzed the data carefully, it is found that there are various linguistic aspects exploited by the cartoonists as source of jokes for their creations. Based on the hierarchical levels and the closeness of one with others, from the most common to the least, those aspects are sound change, polysemy, idiom, homonym, antonym, pragmatic usage. These matters will be discussed in the following sections:

\subsection{Sound Change}

Sound change is the lowest level in punning creation. This word play might be created by substituting, deleting, inserting, or permuting the sound(s) of word to become another word with very different meaning if applied in the same utterance context. For examples, reklamasi 'reclamation' has totally different meaning proklamasi (proclamation); internet 'internet' and eternit 'plasterboard'; and makar 'coup de tat' and makan 'eating'. See the following (3), (4), and (5) which are consecutively inspired by reclamation plan carried out to several coasts al areas with its potentials to cause environment destruction, intention of some suspects to coup Jokowi's government, and information technology advances that cannot be followed by the older generations.

(3) A: Reklamasi ing Teluk Jakarta mandheg sawetara?

'Reclamation in Jakarta gulf was stopped temporarily.'

B: Proklamasi, wis merdika kok isih aeng-aeng.

'Proclamation? It is already independent now. Why are you still strange?'

A: Gawe dharatan kanthi ngurug pesisir iku jenenge reklamasi, Mbah!

'To make a land by covering the coastal area is called reclamation, Grandpa!

(Djaka Lodang, No.48/30/4/2016 p. 41)

(4) A: Cah saiki pancen aneh, nonton siaran teve ora liwat teve nanging komputer.

'People nowadays are really strange, watching television broadcast is not through television, but a computer.' 
B: Iki jenenge video streaming. Nonton teve liwat internet.

'This is called streaming video. Watching television through internet.'

A: Luwih aeng meneh, eternit kok ditonton?

'Even more strange, why do you watch a plasterboard?'

(Djaka Lodang, No. 18/1/10/2016 p. 17)

(5) A: Aja gelem yen ana sing ngajak makar, bisa dadi urusan pulisi.

'Don't accept, if there is someone invite you to do a coup de tat, later you will have a problem with the police.'

B: Paling enak yen ana sing ngajak makan.

'The most enjoyable, if there someone invites us to eat.'

A: Yen kakehan paling apes mung kemlakaren

'If too much, at the most, it just causes unserious stomach problem'

(Djaka Lodang, No. 29/17/122016 p. 41)

\subsection{Polysemy}

Polysemy is an an emic expression which has more than one meaning. Each meaning is related to others by the same core. For example, the Javanese word weruh 'know' at least can be used to express several senses. Those are 'to know', 'to see', 'to address', 'to responsible', and 'to frighten'. All of these senses are related with one core meaning 'to know' as shown in (6) to (9) below:

(6) Aku ora weruh apa-apa bab perkara kui.

'I don't know anything about that matter.

(7) Mripatku ora weruh nek gelas kui ana meja. 'My eyes could not see if the glass was on the table'

(8) Wong loro kui ora weruh-weruhan.

'The two people did not address each other'

(9) Dheweke diweruhi sing tunggu wit gedhe pinggir kali

'He was frightened by the ghost of the big tree near the river side'

The word ngetokna in Javanese is polysemous. Its primary meaning is 'to put something out', but in a certain context can also mean 'to give birth'. In the frame of cooperative principle theory, to make the surprising expression reasonable, he must mean the word ngetokna of his utterance 'to give birth a cow', instead of a common event 'to put her cattle outside the barn'. This semantic ambiguity is exploited in discourse (10):

(10) A: Desa sebelah ana wong meteng ngetokna sapi

'In the neighborhood village, there was a pregnant woman bore a cow'.

B: Mbah'e ngarang..mosok wong isa nglairna sapi?

'Grand $\mathrm{Pa}$, you are really bullshit. How could a woman bore a cow?

A: Sing dimaksud iku wong meteng ngetokna sapine saka kandhange, Ndhez

'What I mean is a pregnant woman taking out her cow from the barn, stupid'

(Djaka Lodang, No. 30/7/2016, p. 50)

Theoretically, linguistic meaning can change because of socio-cultural factors. The meaning of sekolah 'school' primarily only refers to 'a place to educate people'. Yogyakarta's social conditions as an educational center in Indonesia enables to extend the meaning of sekolah to 'a place for pawning goods or possessions'. The students in this city often use this term when they have to pawn their articles, such as type writer, watch, jewelry, hand phone etc. because they use up their money, and will take those things back when they receive the living allowance from their parents. This condition is described by (11) below:

(11) A: Pakdhe, ternyata sing sekolah iku orak uwong thok, sueer!!

'Uncle, apperently the one who can go to school is not merely human..., swear!!'

B: EEh? Ngrumor Le, semut, sapi, jaran pa disekolahna.. Rak Lucu.

'Eeh? That 's a rumor, kid.. can someone send an ant, a cow, or a horse to school? It is really not funny.' 
A: HP..laptop..emas..BPKB, sertipikat..elektronik isa disekolahake ing pegadaian.

'Hand phone, laptop, gold ..certificate, even motor ownership certificate, electronic equipment can be sent to school at a pawnshop.'

(Djaka Lodang, No. 07/167/2016 p. 50)

Very often cartoonists play upon the literal and figurative meaning of a word. In discourse (12) the word meninggalkan which literally means 'to leave something' are combined with its figurative meaning by framing its use in a proverb. So, meninggalkan keluarga 'leaving family' is the literal sense, but meninggalkan nama 'leaving names' is the figurative one. In (13) the meaning of mental revolution, the president's slogan which is intended to be figuratively associated with the positive sense 'to change the mindset' is interpreted literally as mental retardation or abnormality.

(12) A: Gadjah Mati meninggalkan gading..Harimau Mati meninggalkan belang.

'Elephant dies leaving ivory.. Tiger dies leaving stripes.'

B: Manusia mati meninggalkan nama...ngono!

'People die leaving reputation. ..like that.'

A: Super salah. Sing bener meninggalkan keluarga.

'It is absolutely wrong. The right answer is leaving their family.'

(Djaka Lodang No. 38/18/2/2017, p. 50)

(13) A: Wis setaun pemerintahan Jokowi JK.

'Jokowi's government has already been a year.'

$\mathrm{B}:$ Mentalmu wis ngalami revolusi durung?

'Has your mentality experienced a revolution?'

A: Popog wae, ndak dikira owah.

'It just remains still, I don't want everyone thinks of me abnormal.'

(Djaka Lodang, No.22/31/10/2015, p. 50)

Anything related with Sexual matters is very sensitive to arise humor (See Wijana, 2009, p. 363-364). Accordingly, the cartoonists, by all means, often create the meaning of words to have an association with such matters, especially when they intend to criticize the embellishment of betrayal or dishonest cases. For examples, the pornographic associations of the Javanese word lembur in (14) 'work over time'are made possible because of its relation to Netty, the woman secretary with whom the man does the overtime work. Likewise, the meaning of diwakili 'to be represented' in (15) is caused by its occurrence with Lastri, the woman house maid who served the man patiently.

(14) A: Kabare sampeyan selingkuh karo sekretarismu Netty. 'There is a rumor, that you are unfaithful with your secretary, Netty?'

B: Ahh ora..wong khusus tugas kantor...Mung kala-kala ya tak jak lembur.

'Oh no, that is only for official business. But, only sometimes I invite her to work overtime'. Thuink.....

'Thuink (The wife threw a shoe, and hit the husband's head'

(Djaka Lodang, No. 32/8/1 2016. P. 50)

(15) A: Sepurane, Pak, baliku rada telat diampirke dik Joni gayeng banget.

'I am sorry, Darling. I will be home late. I stopped off by Joni. It was really very cheerful.'

B: Ora papa Bune tugasmu wis diwakili Lastri .. Full tlaten ngladeni butuhku.

'It doesn't matter, honey. Your task is already represented by Lastri. She was very patient and careful to serve all I need'

C: Lho,....

'Oh...my god'

(Djaka Lodang, No. 33/8/2016. p. 50)

Finally, slight semantic differences that exist in polysemy are exploited by the cartoonist through analogy, as shown in (16) in which the Javanese word anyar 'new' might have other nuances, such as 'recent', 'modern', 'sophisticated', etc. in relation with corruption strategy that brings anxieties for the government to succeed eradicating this crime. 
(16) A: Taun anyar 2016 duwe pemimpin KPK anyar.

'New year 2006, Indonesia has a new KPK head'

B: Gedhunge ya anyar

'The building is also new'

A: Nanging kok sajake ana sing isih dikuatirke.

'But, it looks that you still have something to worry about.'

B: Koruptore duwe strategi anyar sing luwih sistemik.

'The corruptor also have a new and more systemic strategy.'

(Djaka Lodang, No. 32/8/1 2016. p. 27)

\subsection{Idiom}

Idiom is any linguistic expression which consists of two or more elements whose meaning can not be interpreted from the literal meaning of its elements. For example, the idiom Tanah air means 'mother land'. This meaning is totally different from the meaning of its basic element tanah 'land' and air 'water'. So, if this idiom occurs with verb membela 'to defend', the meaning will refer to patriotic awareness of all citizens to sacrifice their soul to defend 'the mother land'. For creating joke to criticize social poverty, idiomatic expressions are often treated as unidiomatic ones, and their constituents are interpreted literally. See the following (17), one of the characters (B) comprehend tanah air as 'land' and 'water', instead of 'mother land'.

(17) A: Sebagai putra bangsa harus siap membela tanah air.

'As a son of the nation, we must always be ready to defend our mother land.'

B: Omah ngontrak, tanah ora nduwe, air gur crat-crit, apa sing dibela

'I rent a house, I don't have a land, the water tap doesn't run well, so there's nothing to defend.

C: Lho, iki jur piye?

'So, how come with these all?'

(Djaka Lodang, No. 23/5/11/2016 p. 50)

Meanwhile, idiom mata kaki which consists of mata 'eye' and kaki 'foot' means 'ankle', only figuratively has a relation with mata that means 'eye'. The confusion usage of these two types of meaning (literal and idiomatic meaning) is exploited by the following (18), a dialog between two homeless people who are always chased by Satpol PP 'city security apparatus':

(18) A: Dengan "mata kepala" sendiri tak delok mau operasi Satpol PP, Yu.

'With my own eyes, I saw there was a public order operation'

B: Yes, aku suer percaya kang beritamu, masalahe nek "mata kaki" kan ora isa nggo delok..oke Kang?

'Yes, swear I do believe in your news, because you cannot use your ankle to see, right?

(Djaka Lodang, No. 51/21/5/2017 p. 50)

\subsection{Homonymy}

Different from polysemy, homonym is two or more linguistic expressions that accidentally have identical sound and or spelling. Total homonym has similarity in both sound and spelling, but partial homonym is only identical in one respect, sound or spelling only. In English, the word bank that refer to 'the side part', such as in riverbank have the same sound and spelling to another expression that means 'money institution, such as in world bank. Meanwhile, the English word night and knight or soul and sole are only identical in sound, and the word bow that means 'to move down head or top half of the body' and bow that means 'a weapon used for shooting arrows' are only identical in spelling (Hornby, 2015, p. 732). The relation that holds in the bank is total homonym, while the relation in night and knight; soul and sole; and the bow is a partial homonym. The resemblance in sound is called homophone, and the resemblance in spelling is called homograph. The Javanese word rai means 'face', and rai gedheg that literally means 'woven bamboo face', is an idiomatic expression to refer to a shameless person. This word accidentally has the same sound with Ray as part of a popular Indian movie star's name Ray Kapoor. This homonymic phenomenon is exploited in the following (19) in which a rich person insults disrespectfully a poor person, and this insult arises from the poor's anger.

(19) A: Ndara, bintang film India namine 'Ray Kapoor'. Nek Indonesia sinten nggih? 
'Sir, an Indian film star's name is "Ray Kapoor". And what is Indonesian film star's name?'

B: Neng kene jen enge iku Rai Gedheg. Persis kowe.

'In here the name is "Rai Gedheg". It is totally like you'.

A: Sumangkean, peh lagi dadi 'Ndara'.. Titenana mengko!

'You are really arrogant, just because you are a boss now. But be careful, what will happen to you next!'

(Djaka Lodang, No. 34/23/12016, p. 50)

A homonymic pair can also be made through acronymic creation, as shown in (20). Canggih 'sophisticated' is a Javanese loan word through Indonesian. This word is made homonymous by treating it as an acronym of ngapurancang karo nggih-nggih 'standing with two hands in front while repeatedly saying yes as a sign of obedience, but uncreative husband.

(20) A: Wonk lanank "canggih", tapi ora ngerti karepe bojo.

'A sophisticated husband but doesn't know what the wife needs'.

B: "Canggih" tegese ngapurancang karo nggah-nggih, gitu lho!'

"Canggih" means "standing with two hands in front" and always say "Yes".

C: Wow..Rada mlengse Rak Ngira.

'Oh, you are rather abnormal, I have never realized it before.'

(Djaka Lodang, No. 22/31/10/ 2015 p. 50)

One member of homonymic pairs might be a shortened form of a phrase through contraction process. For example, the Javanese phrase ora usah 'not necessary' consists of two words ora 'no' and usah 'need or necessary'. This phrase can be shortened to become rasah in a nonformal speech situation. This short form accidentally has similar sound with rasa 'taste or flavor'. The following (21) is created on the basis of this homonymic combination.

(21) A: Whuih, es juz nyamlenk... Mbak yu..juz paling enak niku rasa napa nggih? 'Oh, juice ice, very delicious! What juice does have the most delicious taste?'

B: Rasah Mbayar Jelas?!

'It is clear, no need to pay'

(Djaka Lodang, No. 27/ 5/12/2015, p. 50)

The combined forms can also be nearly or partly homophone, such as the punning of pari 'rice', parikan 'poem', parikena 'unserious criticism', pariwisata 'tourism', and Paridin 'personal name' in (22):

(22) A: Pari isa dadi parikan, parikena, pariwisata, ning ana pari sing nyebeli, njengkelke.. Paridin sampeyan dhewe!

'Pari may become parikan, parikena,pariwisata, but there is also pari who is disgusting and annoying, Paridin, that is yourself'.

(Djaka Lodang, No. 31/31/122016, p. 50)

Finally, homonymy found in (23) are caused by complicated Javanese morphological process. This cartoon is inspired by bush fires that often happen because of land extension for palm oil plantation. The ambiguous Javanese poly morphemic word macane can mean 'the tiger' from < macan 'tiger' $+\mathrm{e}>$ and 'how to read' from $<\mathrm{N}-+$ waca 'read' +-e $>$. The first character (A) in this cartoon wants to know about the tigers (macane) after the bush fire, but the other character (B) interpret it as 'how to read'.

(23) A: Berita "alase kobong"...terus "macane" piye?

'Said that the forest was on fire..and how about the tigers?'

B: Ejaanne tetep ra brubah a-las-e ko-bong.

The spelling has not changed "a-las-e ko-bong".

A: Bener jugak!!

'It is also right'

(Djaka Lodang, No. 28, 12/12/2015 p. 50) 


\subsection{Antonymy}

Antonymy is any matter related to the opposite meaning holds between words, such as male and female, dead and alive, east and west, hot and cold, etc. Generally, the antonymic opposition can be divided into two types. Those are binary opposition and nonbinary opposition (Kreidler,1999, p. 100-105). Binary oppositions are pairs that exhaust all possibilities along the scale. Male and female, alive and dead, etc. are binary antonyms. Anything dead must be not alive, and anything male is necessarily not a female. Nonbinary oppositions are pairs that allow some other possibilities along the scale. East and west, hot and cold, etc. are nonbinary antonyms because these pairs allow other possibilities in between their scale. Between east and west there are north, south, northeast, north west, south-east, and south-west, etc., and between hot and cold there are warm, cool, etc. So, anything not hot must not be cold, it can also be warm or cool. Likewise, if something is not in the east, it is not necessarily in the west. It can possibly in the north or in south, north-west, etc. Non-binary antonyms can further be classified into several sub categories, such as gradable antonym, like hot and warm, good and bad, etc.; directional antonym like come and go, take and bring, etc.; converse antonyms like above and below, sell and buy, etc.; antipodal antonym, like west and east, north, and south, etc.; orthogonal antonym, like west and north, south and east, etc.

For creating jokes, cartoonist exploits many types of antonym. For instance, cartoon discourse (24) uses the polite form of Javanese binary antonym jaler 'man' and setri 'woman', and its impolite variation lanang 'man' and wedok 'woman' in discussing actual issues of the coming Bantul's (one of Yogyakarta state's regions) mayor election. So, does discourse (25) which is inspired by a dispute in Yogyakarta Palace about the opportunity for a woman to be a king:

(24) A: Dadi...ora...Ora dadi Momet posink piye iki ya?

'To be or... not to be ...My head really spinning.. What can I do?'

B: Mbah... mengke sing dadi bupati jaler napa setri ben, pikire loss

'Grand pa the next mayor will be a man or a woman, to make my mind free?'

C: Trawanganku yen ora lanang...ya wedok...pasti dudu banci.

'In my prediction, if it is not a man, it would be a woman..but must not be an effeminate.'

(Djaka Lodang No. 26/28/11/2015, p. 50)

(25) A: Mbengi iki aku sing dadi Ratu Ok

'Tonight I will play as a king, Ok?'

B: Rung ana crita Ratu kok wedok.

'In the story, there has never been a woman king'

C: Lho, Ratune lanang pa wedok iku tergantung

'Oh, a man or a woman, it depends....'

B: Saka dhapukane sutradara ketoprak tobong iki Betul yas khan?

'On the cast of this ketoprak tobong (traditional play)'s director, right?

(Djaka Lodang No. 42/18/32017, p. 50)

In spite of binary opposition, nonbinary one can also become rich sources to create a joke. Javanese word nom 'young' and tuwa 'old'; ayu 'beautiful' and elek 'ugly'; and ngangeni 'make someone miss' and nyebeli 'disgusting' are gradable antonyms. This type of antonyms is used by the cartoonist in (26) to insult an old man who still enjoys a young girl. In (27) Djaka 'bachelor' is opposed to prawan 'virgin girl' in context of sexual inequality. Domestic foods, such as lontong opor 'rice steamed in banana leaf and curry', gudeg, (sa)te ayam 'chicken skewer', tahu kupat 'rice steamed in young coconut leaf and bean curd' can be opposed to foreign foods, such as beef steak, hamburger, Italian pizza, and marmer bread 'marble bread' for criticizing the younger generations who no longer enjoy or respect their traditional food, as shown by (28).

(26) A: Bune, apa bedane wong wedok nom ayu karo tuwa elek?

'Honey, what is the difference between a young beautiful lady and an old ugly woman?'

B: Neh-aneh, ra ngaruh.

'You are very strange, no difference, I don't care'

A: Jelas beda, wong wedok nom ayu ngangeni, nek wis tuwek elek nyebeli.

'It is obviously different, a young beautiful lady makes someone miss, and after becoming an old ugly woman she will be disgusting.'

(Djaka Lodang No. 11/15/8/2015 p. 50) 
(27) A: Kalawarti iki kok dijenengi Djaka Lodang aneh maksude? 'Why this magazine is named Djaka Lodang. It is strange.. What does it mean?'

B: Kuwi dipilih seka anggitan Den Bei Ranggawarsita. Luwih Joz timbang "Prawan lodang". Rak malah wagu tur rada saru

'This name is chosen from Den Bei Rangga Warsita's creation. It is much better than "Prawan Lodang", even odd and rather immoral'

(Djaka Lodang No. 43/25/3/2017 p. 50)

(28) A: Ikke ngefans itu beef steak en hamburger aih lekker. Pizza Italia plus marmer bread wow nyamlenk..!

'I enjoy beef steak and hamburger, oh very tasty. Italian Pizza plus marble bread, wow, it's really delicious'

B: Seh enak lontong opor, gudeg, tea yam, tahu kupat jos.

'it's still more delicious rice steamed in banana leaf curry, jack fruit vegetable, chiken skewer, rice steamed in young coconut leaf and bean curd, fantastic!'

(Djaka Lodang No. 26/12/11/2016 p. 50)

As such, it is certainly considered countrified to use domestic food, such as geplak 'sweet coconut cake', lemet 'sweet cassava cake wrapped in banana leaf', and thiwul 'dried cassava snack' to be valentine presents, as reflected in cartoon (29):

(29) A: Valentine ing Jogja ora ngadho coklat larang.

'Valentine in Jogja, don't give chocolate. It's expensive!'

B: Tandha tresna saka panjnengan wujud apa?

"What is your love present"

A: Gantine geplak, lemet, apa tiwul.

'I change it with sweet coconut cake, sweet cassava cake, or dried cassava snack.'

(Djaka Lodang, No. 37/13/2/2016 p27)

\subsection{Hyponymy}

The semantic relation that holds between words may involve word having a more generic concept and more specific ones. Such as between cook and fry, boil, steam, stew, etc., or between a taxonomy and its members, such as vehicle and car, motor car, ship, plane, train, etc (Kridalaksana, 1993, p. 74). This semantic relation is called hyponymy. So, cook and vehicle are respectively the hyper names of their co hyponym fry, boil, steam, and stew; and car, motor car, ship, plane, and train. So, alam 'nature' has more generic concept than manusia 'human', binatang 'animal', tanaman 'plant', etc. This type of relation is exploited by the cartoonist in (30) to criticize harshness of senior students to their juniors that frequently happens in Indonesia.

(30) A: Mahasiswa yunior dadi kurban kekerasan seniore . Kedadian iki ing pendhidhikan dasar mahasiswa pecinta alam.

'Junior students became harshness victims of their seniors. The accidents were in the student basic nature lover training.

B: Ngecakake pecinta manungsa wae durung bisa, apa maneh karo alam.

'Even just to be a human lover, they can't, let alone to be a nature lover.'

(Djaka Lodang, No. 36/4/2/2017, p. 43)

\subsection{Pragmatic Usage}

The meaning of linguistic expressions in a lot of cases are tightly bound by its pragmatic usage. The meaning of bedhug 'drum' can be totally different depending on its use in real context. Bedhugin Javanese culture is hung/kept in mesjid 'mosque'. This instrument is beaten at noon for indicating praying time. Accordingly, in a certain context, the use of bedhug can refer to the time when it is beaten to inform the coming of praying time. The following discourse (31) is created on the basis of a pragmatic violation of the word bedhug in which A mislead B because in such context his utterance Bedhug ing ndhi? should mean 'When the drum beaten at noon', instead of 'Where is the drum (is hung/kept)'.

(31) A: Srengenge iku esuk ana wetan, sore ana kulon. Bedhug ing ngendi? 
'In the morning the sun is in the east, evening in the west, and where is it (when the drum sounds)?'

B: Yen Bedhug pasti ing mbun2nan.

'It must be precisely above your head.'

C: Huh.. ngawur bedhug iku ya ing mesjid...!

'Uh..you are reckless, the drum is in the mosque.'

(Djaka Lodang, No. 36, 4/2/2017, p. 50)

The meaning of Javanese polite style utterance of gojek (public transport motorcycle) man in (32) Dalem-e pundi, Mbakis 'where do you live'. So, by getting the answer, he will knows where the passenger must be delivered. It is certainly out of the context and not cooperative if she interpreted that the man will rob her house. She treats the house asked by the gojek man as jewelry and suspects the gojek man as a robber. This is made possible because the literal meaning of the sentence is 'Where is your house?'. Notice, mbak and mas are respectively address terms for female and male, either young or adult.

(32) A: Gojek, Mas.

'Hei, gojek.'

B: Nggih, Mbak. Lha Dalem-me pundi, Mbak?

'Yes...and where do you live?'

A: Ra tak gawa. Crigis takon omah barang, arep sembrana.

'I don't bring it. Why do you ask my house, You must have a bad intention.'

(Djaka Lodang, No. 39/2/2017, p. 50)

A lot of jokes based on pragmatic usage are created by mismatching assumptions between discourse interlocutors, such as ones between a police and a traffic violator in (33) about the strength of helmet and blangkon 'Javanese traditional cap', husband and wife about the magic strength of Tono, a man the wife talks about who is apparently a high way patrol police in (34), between husband and wife about Mr. Dullah who never paid his electric and water bill, but the electricity and the water in his house are not stopped (35). The wife has never realized that in fact Dullah always asks someone for paying those bills.

(33) A: Kowe tak tilang ora nganggo helm, malah nganggo blangkon!?

'I arrest you. You didn't wear a helmet, instead, you wore a Blangkon!

B: Helm dibanting pecah remuk. Blangkon aman... oke?

'Helmet would be broken into peace if it was slammed down. But blangkon is safe, ok!

A: Whela, ketanggor strip.

'Oh, I really met a mad person!!

(Djaka Lodang, No. 44/1/4/2017, p. 50)

(34) A: Tono saikine dadi wong sekti hebat percaya, ra? Dheweke isa ngendhekna tronton gur tangan siji.

'Tono now becomes a powerful man. He is really extraordinary. Believe or not? He can stop a big truck with one hand.'

B: $L h o, \ldots$.

'Oh....'

A: Tono iku polantas ... Isa nyetop nggo tangan siji.

'Tono is a high way patrol..can stop any vehicle with one hand.'

(Djaka Lodang, No. 21/ 22/102016, p. 50)

(35) A: Wiwit biyen Pak Dullah ora tau mbayar PAM karo PLN

'It has been for along time, Mr. dullah has never paid water and electricity bills.'

B: Mokal...aja nggosip. Ora mbayar mesthi diputus.

'Bullshit, don't tell a gossip. If he did not pay, they wold be stopped.'

A: Dheweke ngongkon wong liya..ora mbayar dhewe.

'He asked someone to pay it...He did not go to pay the bills himself.'

(Djaka Lodang No. 20, 15/10/2016, p.50) 
Sometimes, the cartoonist opposes linguistic expressions of different grammatical level which is unseen in writing version, such as shown by the following (36) in which digawa wong mati can mean "brought by the dead person" as interpreted by his daughter and 'brought by a person, and ceased /off'. Wong mati 'dead person' is noun phrase and (digawa) wong, (trus) mati '(brought) by a person, and ceased/off is a clause.

(36) A: Yen nyata cerdas, coba bedheken apa sing digawa wong mati?

'If you are really bright, please guess! What is brought by the dead person.'

B: Sing mesthi nggih amal sae napa awon.

'it must be a good or bad deed.'

A: Salah ndhuk...digawa wong mati iku lilin ditiup angin lesus...

'It is wrong. Something brought by people, and ceased/off is a candle blown in whirl wind.'

(Djaka Lodang, No. 25/19/11/2016, p. 50)

Kerokan 'coin treatment' is one of the most common ways of healing air sickness in Javanese culture. The coin is scratched along, forming lines on the back, chest, arms, etc where the sickness is felt, but never on the head although the healed person suffers from a headache during the air sickness. This assumption is flouted in (37) in which the wife scratches the coin on the back part of her husband's head. For enjoying the joke, the discourse should no be separated from the drawing panels.

(37) A: Bune sirahku ngelu tulung dikeroki!

'Honey, my head is terribly dizzy. Please, rub with a coin!'

(Djaka Lodang, No. 23/7/11/2015, p. 49)

\section{Conclusions}

Even though the use of Javanese in Indonesian community is declining from time to time, its communicative functions to serve its speakers for conducting informal or less prestigious activities are still well preserved. One of those activities is expressing jokes. Even for this purpose, this regional language is seemingly considered more appropriate than the very formal Indonesian which is tightly governed by grammatical rules which will impede the lavishness of the speakers in telling the jocular expressions. These expressions are intended to gain comic effects which in turn enable to elicit smile and laugh of the audience. As far as cartoon discourses are concerned, these effects are achieved by violating conversation maxims of cooperative principle rules which are tightly obeyed by the interlocutors in non-humor or conventional discourses. By this violation, the assumptions which will certainly be realized in the utterance by one interlocutor are unexpectedly canceled in such a way by the other. There are various linguistic aspects which are commonly exploited by the cartoonists to flout the conversational rules. Those aspects are polysemy, idiom, homonymy, antonymy, hyponymy, and pragmatic usage.

Like other jocular genre texts, cartoon data presented above are not merely created for the sake of amusing the audience, their existence is also often motivated by delivering social criticisms about various problems occur in the speakers' community, such as criticism against social poverty, injustice, crimes, betrayals and dishonesty, violence, boss and employer impoliteness, environment destruction, etc. Therefore, the study humor cartoon discourse and other types of humor texts across disciplines, and linguistics with no exception play a very important role in order to understand and help to overcome social problems happen in the society.

Shortly, informal Javanese still plays an important role in delivering various communicative functions among its community members. Therefore, its existence should be continuously maintained by its speakers, especially the younger generation to keep sustaining the auspicious of Javanese culture. Cartoon is just one genre of hummorous discourse, many other types of the sort, such as riddle, traditional songs, slippery talk (plesetan), etc. which are abbundant in the use of Javanese are interesting objects to study in the future.

\section{References}

Allan, K. (1986). Linguistic meaning (Vol. I). London: Routledge \& Kegan Paul. 
Anwar, K. (1980). Indonesian: The development and use of a national language. Yogyakarta: Gadjah Mada University Press.

Apte, M. L. (1985). Humor and laughter. Ithaca: Cornell University Press.

Grice, H. P. (1975). Logic and conversation. In Cole, P. \& Morgan, J.L. (Eds). Syntax and semantics 3: Speech acts. New York: Academic Press (pp 41-58).

Grotjahn, M. (1957). Beyond laughter. New York: McGraw-Hill.

Halim, A. (1981). Fungsi politik bahasa nasional, politik bahasa nasional. [The political function of national language, politics of national language]. Jakarta: Balai Pustaka. [In Bahasa Indonesia].

Holmes, J. (1992). Introduction to sociolinguistics. London: Longman.

Hornby, A. S. (2005). Oxford advanced learner's dictionary. Oxford: Oxford University Press.

Jatmiko, S. (2009). Urip mung mampir ngguyu: Telaah sosiologis folklor Jogja. [Life just laughing: sociological study of Jogja's folklore]. Yogyakarta: Kanisius. [In Bahasa Indonesia].

Kreidler, C. W. (1999). Introducing English semantics. London: Routledge.

Kridalaksana, H. (1993). Kamus linguistik edisi ke-3. [Linguistic dictionary $3^{\text {rd }}$ edition]. Jakarta: Gramedia Pustaka Utama. [In Bahasa Indonesia].

Maryaeni. (2001). Bahasa Jawa dalam ludruk di Jawa Timur: Studi tentang tatakrama bahasa. [Javanese language in Ludruk at East Java: Study of language manners]. [Doctoral Dissertation from Universitas Gadjah Mada Yogyakarta]. [In Bahasa Indonesia].

Moeliono, A. (2011). Kebijakan bahasa dan perencanaan bahasa di Indonesia: Kendala tantangan. perencanaan bahasa pada abad ke-21: Kendala dan tantangan. [Planning of language in $21^{\text {st }}$ century: constraints and challenges]. Jakarta: Badan Penngembangan dan Pembinaan Bahasa Kementrian Pendidikan dan Kebudayaan. [In Bahasa Indonesia].

Parker, F. (1986). Linguistics for non-linguists. London: Francis \& Taylor Ltd.

Pradopo., S. W., Maharto, S. S., \& Faruk H.T. (1985). Humor dalam sastra Jawa modern. [Jokes in modern Javanese literature]. Yogyakarta: Proyek Penelitian Sastra Indonesia dan Jawa. [In Bahasa Indonesia].

Raskin, V. (1984). Semantic mechanisms of humor. Dordrecht: D. Reidel Publishing Company.

Romaine, S. (1989). Bilingualism. Oxford: Basil Blackwell.

Wijana, I. D. P. (1995). Wacana kartun dalam bahasa Indonesia. [Cartoons discourse in Indonesia]. [Doctoral Dissertation from Universitas Gadjah Mada Yogyakarta]. [in Bahasa Indonesia].

Wijana, I. D. P. (2003). Kebijakan bahasa dan dinamika bahasa-bahasa daerah di Indonesia. In Sumiyati A.S. (Eds.). Dinamika Budaya Lokal dalam Wacana Global. [The dynamics of local culture in global discourse]. Yogyakarta: Unit Pengkajian dan Pengembangan Fakultas Ilmu Budaya Universitas Gadjah Mada. [In Bahasa Indonesia]. [Unpublished]

Wijana, I. D. P. (2009). "Sexual problems in proverbial puns”. Lenses. F.X. Nadar \& Topan Dwi Hardjanto (Eds.). Faculty of Cultural Sciences Universitas Gadjah Mada. [Online unpublished]

Data Sources

Djaka Lodang, Yogyakarta, PT Djaka Lodang Pers. http://www.djakalodang.co.id/ 